УДК 911.3

DOI:https://doi.org/10.15407/ugz2020.01.007

\title{
Ю.М. Палеха
}

Державне підприємство «Український державний науково-дослідний інститут проектування міст «ДІПРОМІСТО» імені Ю.М.Білоконя», Київ

\section{НОВА РЕДАКЦІЯ ГЕНЕРАЛЬНОЇ СХЕМИ ПЛАНУВАННЯ ТЕРИТОРІЇ УКРАЇНИ - СТРАТЕГІЯ ІНТЕГРАЦІЇ УКРАЇНИ У ЄВРОПЕЙСЬКИЙ ПРОСТІР}

Метою цієї публікації є аналіз недоліків і проблем, пов’язаних з діючою Генеральною схемою, встановлення передумов розроблення іiі нової редакції та визначення основних наукових та практичних принципів виконання. Викладено основні аспекти розроблення нової редакції Генеральної схеми планування території України. Діюча Генеральна схема була затверджена Законом України 7 лютого 2002 року. Термін ії дії завершується у 2020 році. Програмою діяльності Кабінету Міністрів України передбачено розроблення нової Генеральної схеми у найближчі роки. Встановлено, що основними питаннями, які потребують вирішення у новій Генеральній схемі, є: побудова планувального каркасу, пов'язаного з європейським планувальним каркасом (в основу якого покладені міжнародні транспортні коридори $\mathrm{TIN}$ ); використання переваг точок зростання; розвиток функціональних регіонів (Азово-Чорноморське узбережжя, Українські Карпати, прикордонні регіони, міські агломерації тощо); розбудова Національної екологічної мережі на базі Смарагдової мережі України; розвиток сучасної системи розселення; зміна структури використання земель і підвищення частки природоохоронних та рекреаційних територій. В основу рішень Генеральної схеми має бути покладена затверджена Стратегія регіонального розвитку України до 2027 року. Нова Генеральна схема має створюватись як інтерактивна геоінформаційна модель у єдиній державній референцній системі координат УСК-2000, загальнодоступній для використання органами державної влади та місцевого самоврядування і включати прогнозні карти за такою тематикою: Планувальна структура (планувальний каркас) території України; Функціональне зонування за видами переважного використання; Комплексна оцінка території; Система розселення і перспективний адміністративно-територіальний устрій держави; Система транспорту; Екологічний каркас. Така інтерактивна моделююча система буде актуальною для визначення стратегії просторового розвитку на основі положень Державної стратегії регіонального розвитку України до 2027 р. і водночас буде здатна оперативно реагувати на зміни, які відбуваються в державі на основі інформації щодо природного, економічного, соціального, демографічного та інших потенціалів її території та відповідно корегувати стратегію іiі розвитку.

Ключові слова: Генеральна схема планування території України; просторове планування; Державна стратегія регіонального розвитку; геоінформаційні технологї.

\section{Yu.M. Palekha}

State Enterprise Yu .Bilokon Ukrainian State Scientific-Research Institute of Urban Design "DIPROMISTO", Kyiv NEW EDITION OF THE GENERAL SCHEME OF PLANNING OF THE TERRITORY OF UKRAINE - STRATEGY OF INTEGRATION OF UKRAINE IN THE EUROPEAN SPACE

The main aspects of the development of the new version of the General Scheme of Planning of the territory of Ukraine are outlined. The current General Scheme was approved by the Law of Ukraine in February 7, 2002. It expires in 2020. The activity program of the Cabinet of Ministers of Ukraine envisages the development of a new General Scheme in the coming years. It is established that the main issues that need to be addressed in the new General Scheme are: the construction of a planning framework linked to the European Planning Framework (which is based on the international transport corridors TIN); taking advantage of growth points; development of functional regions (Azov-Black Sea coast, Ukrainian Carpathians, border regions, urban agglomerations, etc.); development of the National Ecological Network on the basis of the Emerald Network of Ukraine; development of a modern settlement system; changing the structure of land use and increasing the share of nature conservation and recreational areas. The decisions of the General Scheme should be based on the approved Strategy for Regional Development of Ukraine until 2027. The new General Scheme should be created as an interactive geoinformation model in the unified state reference system of USC-2000 coordinates, publicly available for use by public authorities and local governments, and include the following main maps: Planning structure (planning framework) of the territory of Ukraine, functional zoning by types of preferred use, comprehensive assessment of the territory, system of settlement and perspective

() Ю.М. Палеха, 2020 
administrative-territorial structure of the state, transport system, natural framework. Such an interactive modeling system will be relevant for defining a spatial development strategy based on the provisions of the State Strategy for Regional Development of Ukraine until 2027, and at the same time will be able to respond promptly to changes occurring in the country based on information on natural, economic, social, demographic and other potentials of its territory and adjust its development strategy accordingly.

Keywords: General Scheme of planning of the territory of Ukraine; spatial planning; State strategy of regional development; geoinformation technologies.

\section{Актуальність теми дослідження}

Для кожної держави важливою $є$ наявність стратегії просторового розвитку. Для європейських країн така стратегія $є$ частиною загальної стратегії просторового розвитку Європейського Союзу, закріпленою Керівними принципами СЕМАT ${ }^{1}$, Директивами Європарламенту та іншими документами. Для нашої країни таким документом $є$ Генеральна схема планування території України (далі - Генеральна схема, Генсхема).

Генеральна схема була розроблена протягом 1999-2000 років і затверджена відповідним законом ${ }^{2}$. Вона стала першим на пострадянському просторі документом, що визначає концептуальні підходи до вирішення планування та використання території нашої держави на достатньо тривалий час -20 років. Аналогічні роботи розроблені у державах СНД або пізніше (Білорусь, Казахстан), або стосувались вирішення лише однієї сфери (наприклад, Генеральна схема розселення Російської Федерації).

Термін дії нинішньої Генсхеми закінчується у 2020 p. У 2019 р. Постановою Кабінету Міністрів України ${ }^{3}$ передбачено розроблення у найближчі роки нової Генеральної схеми, яка має стати механізмом інтеграції України у загальноєвропейський простір. Це ставить перед науковцями та фахівцями завдання у найкоротший термін визначити науково-практичні засади розроблення цього важливого документу, що й визначає актуальність цієї публікації.

\footnotetext{
${ }^{1}$ Керівні принципи сталого просторового розвитку Європейського континенту. Переклад та розмноження за сприяння проекту «Інноваційні регіони CEMAT (GTZ, Німеччина)», 2007. 40 с.

2 Закон України «Про Генеральну схему планування території України» / Відомості Верховної Ради України (BВР). 2002. №30. ст. 204.

${ }^{3}$ Постанова Кабінету Міністрів України від 29 вересня 2019 р. №849 «Про затвердження Програми діяльності Кабінету Міністрів України»URL: http://w1.c1.rada.gov. ua/pls/zweb2/webproc4_1?pf3511=66959
}

\section{Стан вивчення питання}

Дослідження ролі й місця Генеральної схеми у системі містобудівної документації (документації $з$ просторового планування ${ }^{4}$ ) здійснювалося як у теоретичній, так і в практичній площинах. У цьому аспекті слід виділити дослідження Ю.Білоконя [1-44], В.Нудельмана [5], Ю.Палехи [6-8], I. Фоміна [1] та інших. Однак, аналіз передумов та засад розроблення нової редакції Генеральної схеми в сучасних умовах практично відсутній і обмежується пропозиціями, що містяться у щорічних матеріалах моніторингу Генеральної схеми, який виконало Державне підприємство «Український державний науково-дослідний інститут проектування міст «ДІПРОМІСТО» імені Ю.М. Білоконя.

Мето ю цієї публікації $є$ аналіз недоліків і проблем, пов'язаних 3 діючою Генеральною схемою, встановлення передумов розроблення їі нової редакції та визначення основних наукових та практичних принципів виконання.

\section{Виклад основного матеріалу}

Розроблення Генеральної схеми планування території України стало безпрецедентним кроком у вітчизняному містобудуванні. До участі у розробці були залучені провідні фахівці «ДІПРОМІСТО», а також представники наукових установ НАН України (Інститут географії, Інститут зоології, Рада по вивченню продуктивних сил, Міжвідомча комплексна лабораторія наукових основ заповідної справи), Мінекономіки (Інститут економіки), Держбуду (НДІ теорії і історії архітектури і містобудування, УкрНДІцивільсільбуд), Академії аграрних наук (Інститут землеустрою), провідних вчених та спеціалістів інших наукових закладів, центральних та місцевих органів виконавчої влади. Авторський колектив розробки Генеральної схеми (Ю. Білоконь - керівник, Т. Губенко,

\footnotetext{
4 Тут і далі автор як пріоритетний застосовує термін «просторове планування» за винятком випадків, які стосуються чинного законодавства.
} 
В. Муха, В.Нудельман, Ю.Палеха, В. Присяжнюк, Е. Шаповалов) у 2003 р. був удостоєний Державної премії України у галузі архітектури.

Документація з Генсхеми включає 28 карт, а також пояснювальну записку і табличні матеріали. Картографічні матеріали виконано на основі цифрової електронної карти України масштабу 1:500 000, наданої підприємством СПАЕРО+ 3 використанням геоінформаційної системи ArcView 3.2 компанії ESRI.

Згідно 3 чинним законодавством, Генсхема $\epsilon$ основою для розроблення документації з просторового планування на регіональному та місцевому рівнях, оскільки визначає стратегічні напрями розвитку системи розселення, транспортної інфраструктури, господарського комплексу та інших сфер на різних ієрархічних рівнях. Матеріали Генсхеми використано при розробленні схем планування територій АР Крим та окремих областей, транскордонних регіонів, схем планування адміністративних районів та генеральних планів населених пунктів.

Разом 3 тим, маємо констатувати, що, незважаючи на високий статус, наданий Генеральній схемі у зв'язку з затвердженням іiі відповідним законом, а також наявність Постанови Кабінету Міністрів України про іiі реалізацію ${ }^{5}$, якою визначено порядок, конкретні заходи та передбачено проведення щорічного моніторингу стану реалізації, розвиток України значною мірою відбувається без урахування іiі рішень, оскільки більшість центральних органів виконавчої влади не обізнані з проектними рішеннями Генеральної схеми та її призначенням.

Однією з причин такої ситуації вважаємо недоступність матеріалів Генеральної схеми для вільного доступу протягом тривалого часу через їх наявність виключно у паперовому вигляді. Лише через 13 років від затвердження графічні матеріали Генсхеми були опубліковані у растровому форматі на офіційних веб-сайтах Мінрегіону та основного розробника - ДП «ДІПРОМІСТО», а частина найважливіших схем також стала доступною у векторному форматі на геопорталі ДП «ДІПРОМІСТО» [9].

\footnotetext{
5 Постанова Кабінету Міністрів України від 29 серпня 2002 р. №1291 «Про забезпечення реалізації Закону України «Про Генеральну схему планування території України» // Офіційний вісник України. 2002. №36. ст. 1695.
}

Аналіз проектних рішень Генеральної схеми та поточних тенденцій просторового розвитку України, з урахуванням новітніх викликів та можливостей, що постають перед нашою державою, $€$ підставою для висновків про втрату актуальності значної частини іiї проектних рішень.

Така ситуація засвідчує один 3 вагомих недоліків чинної Генеральної схеми - інертність. Внесення будь-яких змін до рішень Генеральної схеми може бути здійснене виключно у разі прийняття відповідного законодавчого акту.

Водночас за 20-річний період, що минув з часу розроблення Генсхеми України, і 18-річний період iї реалізації у розвитку нашої держави відбулися істотні зміни, зумовлені як зміною геополітичних умов розвитку України, так і загальносвітовими тенденціями та новітніми підходами. Це - і підписання Україною низки міжнародних угод, положення яких мають ураховуватися при просторовому розвитку, і розвиток національного законодавства, і загальносвітові тенденції зміни клімату, і новітній досвід впровадження відновлюваних джерел електроенергії, і переміщення населення та виробничих підприємств із тимчасово непідконтрольних територій тощо.

У сучасних суспільно-політичних умовах також гостро постає необхідність переоцінки закладених Генеральною схемою прогнозів та перспектив, що зумовлюється анексією Автономної Республіки Крим, наявність окремих районів Донецької та Луганської областей, тимчасово непідконтрольних Україні.

Беручи до уваги ситуацію, що склалася, необхідно розробити принципово нові підходи до територіального розвитку України, які мають враховувати:

- пріоритетність зв'язків 3 європейськими державами і поступову інтеграцію України в європейську спільноту;

- зміни у розвитку системи розселення населення та господарського комплексу окремих областей і адміністративних районів внаслідок переміщення із тимчасово непідконтрольних територій виробничих підприємств, науково-дослідних та навчальних закладів, а також переселення населення;

- децентралізацію державного управління і утворення нових територіальних одиниць об'єднаних територіальних громад;

- пріоритетність розвитку функціональних регіонів у Європі, визначену положеннями резолю- 
ції 17 Конференції CЕМАТ у Бухаресті [10];

- новітній аналіз природно-ресурсного потенціалу і його можливостей задовольнити сучасні потреби держави та окремих регіонів.

Нова редакція Генеральної схеми має стати якісно новим документом у суспільно-політичному, методологічному і технологічному аспектах. В основу іiі розроблення має бути покладена Державна стратегія просторового розвитку Украӥни.

Україна ніколи не мала подібного документа, який має бути квінтесенцією геополітичної та геоекономічної стратегій розвитку, військової доктрини, планувальної моделі, постулатів сталого розвитку та інших стратегічних документів. У Державній стратегії має бути відображена роль України як однієї з найбільших держав Європи, що в транзитним «містком» між Заходом і Сходом і одночасно, виходячи iз сучасних реалій, - своєрідним бар'єром на шляху реалізації агресивних планів Російської Федерації.

Досвід європейських держав (зокрема Польщі [11] та Угорщини $[12,13])$ засвідчує, що практично в кожній 3 них свого часу було розроблено Державну стратегію просторового розвитку.

Нині завершується розроблення Державної стратегії регіонального розвитку України на період 2021-2027 рр., в якій беруть участь провідні науковці України, а також представники центральних органів виконавчої влади, громадських організацій. Цей документ, спрямований на реалізацію трьох основних цілей (формування згуртованої країни в соціальному, економічному, екологічному та просторовому вимірах; підвищення рівня конкурентоспроможності регіонів та ефективне людиноцентричне багаторівневе врядування) значно більшою мірою відображатиме саме просторові аспекти регіонального розвитку.

Iз затвердженням Державної стратегії Генеральна схема має стати механізмом іiі реалізації, маючи на меті встановлення загальнодержавних вимог до просторового розвитку окремих регіонів.

На виконання Керівних принципів сталого просторового розвитку Європи, затверджених Європейською конференцією міністрів, відповідальних за регіональне планування (СЕМАТ), зокрема щодо пріоритетів просторового розвитку у Східній Європі, необхідно розробити прог- нозний планувальний каркас території України, який не виконувався у рамках чинної Генеральної схеми.

Різноманітні аспекти формування i розвитку планувального каркасу (планувальної струтури) держави вже неодноразово розглядалися нами у наукових публікаціях [14-15]. Планувальний каркас держави має формуватися як на основі загальноєвропейських транспортних осей - транспортних коридорів, з урахуванням стратегічних внутрішніх зв'язків у межах України, так і наявних або потенційних осей розвитку (наприклад, вісь розвитку вздовж ріки Дніпро).

Основою лінійних елементів планувального каркасу мають стати міжнародні транспортні коридори. Генеральною схемою передбачено розвиток 8 міжнародних транспортних коридорів, які інтегровані у європейську мережу TIN: 3-й, 5-й та 9-й Критські, «Балтійське - Чорне море», «Європа-Азія», «Північ-Південь», Свразійський та ЧЕС. У процесі здійснення щорічного моніторингу Генеральної схеми нами обгрунтована необхідність розбудови ще одного нового автомобільного транспортного коридору «25 меридіан» (Гельсінкі - Таллінн - Рига - Вільнюс - Пінськ - Рівне - Тернопіль - Чернівці - Сучава - Бухарест - Пловдів - Александруполіс), який забезпечить сполучення Балтійського та Балканського регіонів в обхід гірських територій Карпат через територію Рівненської, Тернопільської та Чернівецької областей і тим самим сприятиме економічному розвитку всього західного регіону нашої держави.

Також потребує реорганізації система магістральних залізниць. Необхідно оптимізувати залізничну мережу із забезпеченням транзиту вантажів за стратегічними напрямами та поліпшити залізничне сполучення з країнами Європейського Союзу, зокрема шляхом будівництва транзитної залізничної євроколії у напрямку із Польщі в Румунію, в обхід Карпатських гір. Також доцільно забезпечити швидкісне та безперебійне сполучення південної частини Одеської області (Буджак) із виходом на Румунію за рахунок будівництва мостового переходу через Дністровський лиман та кардинальної реконструкції з частковим новим будівництвом автомагістралі Одеса - Рені.

У контексті зростання ролі морського та авіаційного транспорту у новій Генсхемі необхідно передбачити розвиток портової інфраструктури в Одеській, Миколаївській та Херсонській облас- 
тях 3 можливістю розширення інтермодального транспортного сполучення, насамперед по лінії Балтика - Чорне море, а також розвиток аеропортів із можливим створенням потужних транзитних аеропортів-хабів.

За час реалізації Генеральної схеми розроблено низку заходів, які в окремих випадках коригують проходження автомобільних та залізничних коридорів, будівництво об’їздів окремих населених пунктів. У зв'язку з цим необхідно здійснити коригування транспортної схеми, а також забезпечити урахування в планувальних рішеннях Генеральної схеми новітніх рішень у сфері транспорту, які містяться у схемах планування областей України й у відповідних державних програмах.

Нова, адекватна вимогам сьогодення, модель територіальної структури господарства країни має базуватись на створенні ієрархізованої, поліцентричної мережі полюсів зростання. Як засвідчує світова практика, створення такої мережі $є$ необхідною умовою й у вирішенні проблем просторового розвитку. Дослідженню полюсів зростання i визначенню їх типізації приділено увагу українських науковців [16].

Створення цих полюсів пов'язано зі стимулюванням окремих видів економічної діяльності, що характеризуються потужним мультиплікативним ефектом і поширенням імпульсів розвитку на навколишню територію [16]. В умовах становлення постіндустріального суспільства такими видами економічної діяльності $є$ не тільки промислові виробництва, а й галузі третинного сектора економіки. Отже, в основі формування полюсів розвитку лежить трансформація містоформуючої бази центрів соціально-економічної активності.

У контексті трансформації господарського комплексу необхідно також приділити належну увагу визначенню та реалізації системи заходів щодо перспективного розвитку частини Донбасу, що нині перебуває в зоні конфлікту, після його звільнення із залученням позитивного досвіду реіндустріалізації, структурної трансформації та модернізації старопромислових регіонів Свропи.

Першочерговим завданням, яке постає при розробленні нової Генсхеми, є поєднання лінійних елементів планувального каркасу із системою полюсів зростання, що сприятиме звуженню депресивних ареалів, підвищенню рівня їх соціально-економічного розвитку.
У контексті функціональної типізації території України надзвичайно важливим є рішення, прийняті на останній Конференції CЕМАТ у Бухаресті. Резолюція №1, прийнята за результатами цієї Конференції, має назву: «Функціональні регіони - капіталізація місцевого потенціалу у політиці територіального розвитку європейського континенту» [10]. Тобто, європейські держави задекларували свою увагу на розвитку саме функціональних, а не адміністративних регіонів. При цьому цей розвиток має бути спрямований на розкриття потенціалу місцевих територіальних громад шляхом його капіталізації.

Функціональні регіони розглядаються як регіони, що формуються навколо великих міських центрів, або як території, визначені відповідно до їх географічних характеристик та економічної діяльності. Їх слід розглядати як інструменти для формування державної, регіональної та місцевої політики, яка може сприяти функціональним взаємозв'язкам між територіями, розташованими 3 різних боків державних кордонів (транскордонні регіони - ТКР), сприяючи співпраці на всіх регіональних рівнях та здатні підтримувати збалансований поліцентричний розвиток.

На європейському рівні існує значна різноманітність функціональних регіонів. Вони можуть бути структуровані відповідно до територіальних рівнів (макро-, мезо- та мікро-). До основних типів функціональних регіонів можна віднести ТКР та прикордонні регіони як їх складову частину. До інших типів відносять функціональні міські регіони (міські агломераціі), функціональні сільські регіони, території, що визначаються специфічними географічними, природними та/ або культурними особливостями, а також кластери (географічна концентрація взаємопов'язаних установ та компаній у певній галузі).

На одній території можуть співіснувати кілька типів функціональних регіонів. Тому процес просторового планування має сприяти цілісній перспективі з урахуванням усіх багатофункціональних зв'язків на конкретній території, у межах конкретної громади.

У процесі розроблення нової Генеральної схеми необхідно виділити межі основних функціональних типів регіонів (Азово-Чорноморське узбережжя, Українські Карпати, прикордонні регіони, зони впливу міжнародних транспортних коридорів, міські агломерації тощо) й визначити напрями їх подальшого розвитку. 
Зауважимо, що розроблені в рамках виконання спільних проектів містобудівного розвитку транскордонних регіонів пропозиції щодо їх розвитку вздовж кордонів 3 Польщею, Словаччиною, Угорщиною, Білоруссю, Молдовою мають бути враховані в масштабі цілісної території держави, зокрема слід враховувати пропозиції щодо розвитку вільних економічних зон, логістичних центрів та індустріальних парків.

Необхідно здійснити аналіз акваторій Чорного та Азовського морів в частині виділення функціональних типів використання цих акваторій (природоохоронне, видобування корисних копалин, транспортні комунікації тощо) на підставі методології, розробленої в рамках виконання Схеми планування прибережних територій Чорного та Азовського морів, та наявного в європейських країнах досвіду.

Необхідно також змінити підходи до виділення ієрархії систем розселення держави. Враховуючи формування в Україні об'єднаних територіальних громад (ОТГ) та перспективи утворення нових укрупнених районних територіальних одиниць виникає потреба відкоригувати концептуальні пропозиції щодо формування систем розселення, насамперед в частині міжрайонних та внутрішньорайонних систем. 3 іншого боку, здійснення реформи адміністративно-територіального устрою має спиратися на рішення Генеральної схеми в частині оптимального розподілу повноважень, рівнодоступності послуг i, головне, дотримання принципів людиноцентричності.

Оскільки проектні пропозиції Генеральної схеми спираються на матеріали довгострокового демографічного прогнозу та балансу трудових ресурсів необхідно врахувати дію принципових чинників зміни демографічної ситуації в країні:

- тимчасове вилучення 3 активної господарської діяльності населення АР Крим, міста Севастополь та населення частини Донбасу, тимчасово непідконтрольної Україні;

- переміщення значної частини мігрантів 3 Донбасу та Криму в інші регіони України, при цьому переважна частина цих осіб перебуває в активному працездатному віці;

- збільшення зовнішньої міграції за межі України, спричиненої як політичними, так і економічними факторами.

Повною мірою це може бути забезпечене проведенням повноцінного Всеукраїнського пере- пису населення. Початком у цьому відношенні $\epsilon$ проведення у грудні 2019 р. «електронного перепису» населення за матеріалами державних реєстрів, відповідно до результатів якого чисельність населення України оцінена у 37,3 млн осіб, що $\epsilon$ істотно нижчим показником порівняно 3 даним Держкомстату України.

Стосовно інженерної інфраструктури та іï відображення у Генсхемі необхідно зауважити, що детального опрацювання потребують питання активного розвитку альтернативних шляхів постачання енергоносіїв до Європи, а також будівництва нових нафтопереробних заводів, не передбачених Генеральною схемою, використання додаткових потужностей атомних електростанцій і будівництво додаткових ЛЕП, розвитку власних родовищ нафти та природного газу на шельфі Чорного моря, потенціалу розвитку альтернативних джерел енергопостачання (біоресурси, вітрова та сонячна енергія) та енергоощадних технологій.

Значну увагу у новій редакції Генсхеми має бути приділено екологічним питанням. Зокрема це стосується положень щодо розвитку природно-заповідного фонду, особливо створення значних за площею об'єктів, таких як національні природні парки та регіональні ландшафтні парки, а також проектування національної екологічної мережі відповідно до прийнятого у 2004 році Закону України 6 , які мають значні розбіжності із закладеними в Генеральній схемі перспективами і потребують узгодження 3 розвитком інших галузей. Ратифікація Україною Кіотського протоколу до Рамкової Конвенції Організації Об'єднаних Націй про зміну клімату, запровадження нових вимог щодо поводження з твердими побутовими відходами та низка інших змін у сфері нормування охорони довкілля потребують врахування на рівні планування просторового розвитку держави і відображення їх у Генеральній схемі. Цьому має сприяти створення Смарагдової мережі України (мережа Емеральд), яка органічно поєднується з європейською мережею Natura2000. Важливим процесом екологізації розроблення нової редакції Генсхеми може стати впровадження принципів та засад ландшафтного

\footnotetext{
6 Закон України «Про екомережу України» // Відомо-
} сті Верховної Ради України (ВВР). 2004. №45. ст.502. 
планування, опрацьованих у наукових публікаціях та практичних дослідженнях[17-19].

Зважаючи на природний i культурний потенціал України серед пріоритетних напрямів економічного розвитку слід звернути увагу на туристичну та санаторно-курортну галузь. Основними заходи з підтримки іiі розвитку є вдосконалення існуючої законодавчої бази 3 метою формування сприятливого інвестиційного клімату; розроблення довгострокової програми розвитку та вдосконалення сфери туризму і рекреації 3 метою визначення та підтримки пріоритетних видів туризму і рекреації та відповідних територій; створення містобудівної документації для забезпечення сталого розвитку територій, потенційно придатних для розміщення об'єктів туризму та рекреації, насамперед - вздовж Азово-Чорноморського узбережжя, яке наразі зазнає значного перевантаження і процесів неузгодженої розбудови у зв'язку зі збільшенням попиту, який з'явився 3 анексією Криму. Також необхідний розвиток сільського зеленого туризму, який може стати одним iз пріоритетних напрямів туристичної діяльності. Актуальним є створення мережі спеціалізованих об’єктів туристичної інфраструктури, розташованих поблизу національної мережі міжнародних транспортних коридорів, основних транспортних магістралей та туристичних маршрутів.

Подальший розвиток соціальної інфраструктури має здійснюватися 3 урахуванням істотної трансформації попиту населення на забезпечення об'єктами соціальної інфраструктури, що зумовлено загальносвітовими тенденціями та стрімким розвитком інформаційних технологій. Особливу увагу слід приділити усуненню регіональних диспропорцій у доступі населення насамперед до базових соціальних, комунальних, адміністративних, транспортних, інформаційних та інших послуг.

За останні роки, як свідчать дані моніторингу, почали відбуватися процеси у трансформації структури земель, які не були передбачені Генеральною схемою. Йдеться про істотне зростання площі земель населених пунктів, насамперед сільських. За ретроспективний період площа сіл збільшилася майже на 300 тис. га, тоді як площа міст - лише на 100 тис. га. Таке неочікуване порівняно 3 прогнозами Генеральної схеми збільшення площі населених пунктів за умови одночасного демографічного спаду потребує дослідження причини виникнення цього явища в окремих регіонах. Це зумовлює необхідність актуалізації картографічної основи України з виділенням окремих категорій земель за основним цільовим використанням.

У перспективі необхідно істотно змінити структуру використання території держави 3 наближенням ii до європейських параметрів. Забезпечення оптимізації структури використання території має здійснюватися за рахунок скорочення площі сільськогосподарських угідь, які на сьогодні займають майже 3/4 території України, розширення площі лісів і підвищення лісистості території до рівня, характерного для фізико-географічних умов території України, збільшення площі природоохоронних і рекреаційних територій до рівня, необхідного для забезпечення сталого розвитку території. Необхідно запровадити ефективну, прозору та актуалізовану систему контролю за використанням земель на основі аерокосмічних знімків та ГІС-технологій, здійснити грунтовний аналіз порушень у використанніземель, насампереду приміських зонах великих міст, забезпечивши можливості для збільшення площі територій національної екологічної мережі і зменшення сільськогосподарських угідь.

\section{Висновки}

На підставі аналізу реалізації чинної Генеральної схеми, виявлення недоліків і проблем, пов'язаних 3 нинішніми суспільно-політичними та економічними умовами, змінами у законодавчій базі сформульовано обгрунтовані пропозиції щодо розроблення іiі нової редакції. Діюча Генеральна схема переобтяжена аналізом сучасного стану території та господарського комплексу; із 28 іiї схем 19 по суті містять констатацію фактів щодо того чи іншого аспекта просторового розвитку держави. Тому майбутня Генеральна схема має містити насамперед прогнозні карти, ключовими $з$ яких мають стати:

1. Планувальна структура (планувальний каркас) території України.

2. Функціональне зонування за видами переважного використання.

3. Комплексна оцінка території.

4. Система розселення i перспективний адміністративно-територіальний устрій держави.

5. Система транспорту.

6. Екологічний каркас. 
В умовах надзвичайно динамічної і мало передбачуваної ситуації в державі та інтенсивних змін зовнішнього політико-економічного середовища постає потреба у формуванні Генеральної схеми як інтерактивної моделюючої системи управління державою, що визначатиме стратегію іiї просторового розвитку на основі положень Державної стратегії регіонального розвитку України до 2027 р. і водночас буде здатна оперативно реагувати на зміни, які відбуваються як в державі, так і ззовні, дозволяючи корегувати відповідно стратегію їі розвитку.

Перевагами такої системи є проведення моделювання варіантів просторового розвитку території на основі інформації щодо природного, економічного, соціального, демографічного та інших потенціалів території держави; забезпечення відкритості й доступності матеріалів Генсхеми, а також постійної актуалізації й використання інтегрованих даних щодо господарського і просторового розвитку території держави загалом та іiі окремих регіонів.

Подальший щорічний моніторинг реалізації Генсхеми має забезпечувати виявлення відхилень від запланованих тенденцій, визначення їх причин, виявлення нових можливостей, ризиків та загроз, що впливають на просторовий розвиток України, та формулювання пропозицій щодо внесення змін до Генсхеми для підвищення ефективності розвитку держави.

Розроблення нової редакції Генсхеми має здійснюватися на повноцінній цифровій топографічній основі та з використанням сучасних засобів ГІС-технологій. 3 цією метою має бути створена геоінформаційна система підтримки рішень Генеральної схеми планування території України, технологічно пов'язана із системою містобудівного кадастру.

При цьому першочергового вирішення потребує створення єдиної державної топографо- картографічної основи у референцній системі координат УСК-2000, загальнодоступної для використання органами державної влади та місцевого самоврядування, що дозволить систематизувати усі просторові дані в державі (в регіональному та галузевому вимірах) і заощадити бюджетні кошти.

Для забезпечення відкритості, прозорості та загальної доступності матеріалів Генеральної схеми має бути створено державний веб-портал Генеральної схеми планування території України, на якому будуть відображатися відкриті матеріали Генеральної схеми з урахуванням поточних змін, затверджених Координаційною радою.

Після завершення розробки нової редакції Генсхеми та іiї затвердження Кабінетом Міністрів України пропонуємо внести відповідні зміни до чинного законодавства, передавши повноваження затвердження Генеральної схеми від Верховної Ради Кабінету Міністрів з метою забезпечення узгодженої реалізації проектних рішень та координації дій усіх центральних органів виконавчої влади, діяльність яких стосується просторового розвитку, необхідним є створення Координаційної ради, уповноваженої забезпечувати реалізацію Генсхеми. Такий дорадчий орган має бути очолений уповноваженим віцепрем'єр-міністром України. До складу Координаційної ради мають увійти представники усіх центральних органів виконавчої влади, діяльність яких має вплив на просторовий розвиток держави.

Завдання Координаційної ради полягатиме у визначенні узгоджених заходів із забезпечення сталого просторового розвитку держави на наступний рік на основі розгляду поданих результатів проведення моніторингу реалізації Генсхеми за попередній рік та висловлених залученими сторонами пропозицій щодо подальшого розвитку держави.

\section{References [Jimepamypa]}

1. Bilokon Yu.M., Vladymyrov V.V., Fomin I.A. (2002). Organization of the territory of border regions (conceptual provisions). Monograph. Kyiv, 88 p.[In Russian].

[Белоконь Ю.Н., Владимиров В.В., Фомин И.А. Организация территории приграничных районов (концептуальные положения): Монография. Киев, 2002. 88 с.]

2. Bilokon Yu.M. (2003). Regional planning (theory and practice). Monograph. Kyiv, 246 p. [In Ukrainian]. [Білоконь Ю. М. Регіональне планування (теорія і практика): Монографія. Київ, 2003. 246 с.]

3. Bilokon Yu.M. (2004). Planning of the territory of Ukraine in the conditions of European integration. Approach and prospects of development of the cities of Ukraine, 7, 5-18 [In Ukrainian].

[Білоконь Ю.М. Планування території України в умовах євроінтеграції // Досвід та перспективи розвитку міст України. 2004. №7. С. 5-18.] 
4. Kuybida V.S., Bilokon Yu.M. (2009). Territorial planning in Ukraine: European principles and national experience. Kyiv, 108 p. [In Ukrainian].

[Куйбіда В.С., Білоконь Ю.М. Територіальне планування в Україні: Свропейські засади та національний досвід. Київ, 2009. 108 с.]

5. Nudelman V.I. (2013). Kyiv in the supporting framework of the main lines and nodes of urbanization in Europe: future scenarios. Changes in urban space in Ukraine. Kyiv, 60-72. [In Russian].

[Нудельман В.И. Киев в опорном каркасе главных линий и узлов урбанизации Европы: сценарии будущего // Изменения городского пространства в Украине. Киев, 2013. С. 60-72.]

6. Palekha Yu.M. (2011). Development of the largest cities in Ukraine in the context of resettlement reform. Approach and prospects of development of the cities of Ukraine, 20, 5-23. [In Ukrainian].

[Палеха Ю.М. Розвиток найбільших міст України в контексті реформування системи розселення // Досвід та перспективи розвитку міст України. 2011. №20. С. 5-23.]

7. Palekha Yu.M., Oleshenko A.V. (2014). General scheme of planning of the territory of Ukraine and structural changes in land use (according to annual monitoring of the General scheme). Land management and cadastre, 1, 20-25. [In Ukrainian].

[Палеха Ю.М., Олещенко А.В. Генеральна схема планування території України і структурні зміни у використанні земель (за даними щорічного моніторингу Генеральної схеми) // Землеустрій і кадастр. 2014. №1. С. 20-25.]

8. Palekha Yu.M. (2015). Scientific research at the Institute Dipromisto (retrospective analysis). Approach and prospects of development of the cities of Ukraine, 28, 78-88. [In Ukrainian].

[Палеха Ю.М. Наукові дослідження в інституті «Діпромісто» (ретроспективний аналіз) // Досвід та перспективи розвитку міст України. 2015. №28. С. 78-88.]

9. General scheme of planning of the territory of Ukraine. URL: http://mrbu.maps.arcgis.com/home/index.html [In Ukrainian].

[Генеральна схема планування території України. URL: http://mrbu.maps.arcgis.com/home/index.html]

10. The Council of Europe Conference of Ministers responsible for Spatial/Regional Planning (CEMAT)/ Resolution no.1 Functional areas. Capitalisation of local potential in territorial development policies over the European continent. URL: $\mathrm{https}$ ://rm.coe.int/the-17th-session-of-the-council-of-europe-conference-of-ministers-resp/16807670ac

11. National Spatial Development Concept 2030. (2013). Ministry of Regional Development. Warshaw, 268 p.

12. National Spatial Development Concept (2005). Government of the Hungarian Republic. Budapesht, 53 p.

13. Handbook for the national implementation of the territorial agenda of the European Union: the case of Hungary (2010). Ministry for National Development and Economy Republic of Hungary. Budapesht, 108 p.

14. Palekha Yu.M. (2011). Development of the transport system as a basis for forming the planning framework of Ukraine. Approach and prospects of development of the cities of Ukraine, 21, 4-13. [In Ukrainian].

[Палеха Ю.М. Розвиток транспортної системи як основа формування планувального каркасу України // Досвід та перспективи розвитку міст України. 2011. №21. С. 4-13.]

15. Palekha Yu.M. (2015). Planning framework of Ukraine as a basis for ensuring its sustainable spatial development. Approach and prospects of development of the cities of Ukraine, 29, 48-56. [In Ukrainian].

[Палеха Ю.М. Планувальний каркас України як основа забезпечення іiї сталого просторового розвитку // Досвід та перспективи розвитку міст України. 2015. №29. С. 48-56.]

16. Pidgrushnyi G.P. (2017). Formation of growth poles system in Ukraine as a precondition to its transition to the model of polycentric spatial development. Ukrainian geographical journal, 1, 48-54. DOI: https://doi.org/10.15407/ ugz2017.01.048 [In Ukrainian].

[Підгрушний Г.П. Формування системи полюсів зростання в Україні як передумова іiі переходу до моделі поліцентричного просторового розвитку // Укр. геогр. журн. 2017. №1. C. 48-54. DOI: https://doi.org/10.15407/ ugz2017.01.048]

17. Rudenko L., Maruniak Eu. (2012). Landscape planning and it's importance for sustainable spatial development of Ukraine. Ukrainian geographical journal, 1, 3-8. [In Ukrainian].

[Руденко Л.Г., Маруняк Є.О. Ландшафтне планування та його роль у вирішенні завдань сталого просторового розвитку України // Укр. геогр. журн. 2012. №1. С. 3 - 8.]

18. Rudenko L.H., Maruniak Eu.O., Golubtzov O.G. et all. (2014). Landscape planning in Ukraine. Kyiv, 144 p. [In Ukrainian].

[Ландшафтне планування в Україні / Л.Г. Руденко, С.О. Маруняк, О.Г. Голубцов та ін. Київ, 2014. 144 с.]

19. Ailykova G.V., Golubtzov O.G., Maruniak Eu.O., Palekha Yu.M. et all. (2016). Methods of integration of ecological component of development into spatial planning of Ukraine (regional level). Kyiv, 76 p. [In Ukrainian].

[Методика інтеграції екологічної складової розвитку у просторове планування України (регіональний рівень) / Г.В. Айлікова, О.Г. Голубцов, Є.О. Маруняк, Ю.М. Палеха та ін. Київ, 2016. 76 с.]

Стаття надійшла до редакції 5.09.2019 